AUTHORS:

Paul Kekana ${ }^{1,2}$

Bruce Sithole $e^{1,2}$

Deresh Ramjugernath ${ }^{2}$

\section{AFFILIATIONS:}

${ }^{1}$ Forestry and Forest Products

Research Centre, Natural

Resources and the Environment,

Council for Scientific and

Industrial Research, Durban,

South Africa

${ }^{2}$ School of Chemical

Engineering, University of

KwaZulu-Natal, Durban,

South Africa

\section{CORRESPONDENCE TO:}

Bruce Sithole

EMAIL:

bsithole@csir.co.za

\section{DATES:}

Received: 30 July 2015

Revised: 04 Mar. 2016

Accepted: 12 July 2016

\section{KEYWORDS:}

membrane; retention; flux; fouling; pressure

\section{HOW TO CITE:}

Kekana P, Sithole B,

Ramjugernath D. Stirred cell ultrafiltration of lignin from black liquor generated from South African kraft mills. S Afr J Sci. 2016;112(11/12), Art. \#2015-0280, 7 pages. http://dx.doi.org/10.17159/ sajs.2016/20150280

\section{ARTICLE INCLUDES: \\ $\checkmark$ Supplementary material \\ $\times$ Data set}

\section{FUNDING:}

Council for Scientific and Industrial Research (South Africa); University of KwaZulu-Natal

(C) 2016. The Author(s). Published under a Creative Commons Attribution Licence.

\title{
Stirred cell ultrafiltration of lignin from black liquor generated from South African kraft mills
}

\begin{abstract}
Ultrafiltration of lignin from black liquor was carried out in a stirred batch cell using polyethersulfone membranes. Parameters such as operating pressure, feed concentration, stirring rate and membrane cut-off size were varied and their effects on lignin retention and permeate flux were investigated. The operating pressure, feed concentration and stirring rate were varied in the ranges $150-350 \mathrm{kPa}, 3-9 \%$ and 200-400 rpm, respectively. The membranes used had cut-off sizes of $5 \mathrm{kDa}, 10 \mathrm{kDa}$ and $20 \mathrm{kDa}$. A one-factor-at-a-time experimental design approach was applied in this study. Retention of lignin increased with increases in operating pressure, feed concentration and stirring rate, but decreased with an increase in molecular cut-off size of the membrane. Permeate flux on the other hand increased with increases in pressure, stirring rate and molecular cut-off size of the membrane but decreased with an increase in feed concentration. The extraction of lignin from black liquor was successfully carried out and extraction efficiencies as high as $86 \%$ could be achieved depending on the experimental conditions. The study was concluded with the recommendation of conducting additional experiments using a pilot plant in a continuous mode.

\section{Significance:}

- The extraction of lignin from black liquor was successfully carried out and extraction efficiencies as high as $86 \%$ were obtained. The results can be used to extend the ultrafiltration of black liquor to an industrial scale.
\end{abstract}

\section{Introduction}

The extraction of lignin from black liquor can be achieved by means of acid precipitation, ultrafiltration and the application of selective solvents. ${ }^{1,2}$ The extraction method employed should effectively separate the lignin from the black liquor, without causing an imbalance of the cooking chemicals, $\mathrm{Na}_{2} \mathrm{~S}$ and $\mathrm{NaOH}$. Acid precipitation is the most commonly used method and it has reached the most advanced state of development and implementation. ${ }^{3,4}$ Drawbacks of using precipitation include the use of $\mathrm{H}_{2} \mathrm{SO}_{4}$ which upsets the liquor cycle chemical balance with excess sulfur and the process of filtering and separating the lignin precipitate is hampered by the formation of colloids. ${ }^{4}$ The application of selective solvents such as ionic liquids allows for lignin structures of low molecular weight to be obtained, which are used in the synthesis of high added value products, but with very high production costs. ${ }^{5}$ Ultrafiltration is therefore seen as a promising way of separating lignin from kraft black liquors. The qualities that make membrane processes the ideal technique for separation purposes in biorefineries include their excellent fractionation capability and comparatively low energy requirement. 6,7

The fractionation of lignin by sequential precipitation from softwood industrial black liquor samples collected from different chemical pulping stages was investigated by Alekhina et al. ${ }^{8}$ The authors studied the isolation efficiency as well as the impact of fractionation and pulping severity on lignin structure. It was observed that the spectroscopic characterisation of the isolated lignin revealed significant alteration in its structure and functionalities as a function of the $\mathrm{pH}$, while the alteration in structure and properties of the samples was only marginal. Lignin precipitates isolated at $\mathrm{pH} 10.5$ exhibited the highest purity (lowest content of polysaccharides) while the samples precipitated at a pH of 2.5 revealed the highest carbohydrate content (low purity). These results indicated that up to $85 \%$ of the lignin solubilised in softwood black liquor can be recovered in high purity by lowering the $\mathrm{pH}$ to 5 . Jin et al. ${ }^{9}$ developed a novel membrane-assisted electrochemical approach for the precipitation of lignin from black liquor. In the process, the $\mathrm{pH}$ in the black liquor solution was lowered to 4.7 as a result of water electrolysis, without the addition of acid or $\mathrm{CO}_{2}$, leading to $\mathrm{pH}$-dependent lignin precipitation. In the study it was observed that the electrochemical cell performance was significantly influenced by the condition of the electrolytes. The solution conductivity and the applied current density were also found to play important roles in altering the $\mathrm{pH}$ of the system. In addition, more than $70 \%$ of the chemical oxygen demand value in the black liquor solution was decreased at the set $\mathrm{pH}$, which was comparatively higher than that of the conventional acidic precipitation. This difference was attributed to lignin precipitation and oxidation. The authors concluded that this novel membrane-assisted electrochemical approach may serve as a promising and cost-effective technique for the extraction of lignin and recovery of caustic from black liquor. Velez and Thies ${ }^{10}$ studied the precipitation of liquefied-lignin fractions from a softwood kraft black liquor by acidification with $\mathrm{CO}_{2}$ in a 2-L vessel with a $45^{\circ}$-angle conical bottom to facilitate the collection of liquid-lignin fractions. The process took place at $115^{\circ} \mathrm{C}$ and 6.2 bar over a pH range of 13.6-9.5. In their study, fresh kraft black liquor was used as the feed only for the first fractionation and the partially spent black liquor from the first then served as the feed to the second fractionation, and so on. Seven of these liquefied-lignin fractions were produced from the study and they were found to be highly hydrated phases, containing 32.3-48.2 $w t \%$ water. The authors also concluded that the metal contents in the lignin fractions were significantly reduced compared to the original black-liquor feed.

Several studies have been undertaken to investigate the extraction of lignin from black liquor using ultrafiltration. ${ }^{1-2,6,11-14} \mathrm{~A}$ comparative study on the ultrafiltration of kraft black liquor using different flow modules was carried out by Satyanarayana et al. ${ }^{15}$ The different modules investigated included radial cross flow, rectangular cross 
flow and stirred cell. The authors concluded that the observed rejection and permeate flux were higher in the stirred cell module than with the radial and rectangular cells. Ultrafiltration of black liquor in a stirred batch cell using a cellulose acetate membrane of $5 \mathrm{kDa}$ was carried out by Bhattacharjee and Bhattachary ${ }^{16}$. The membrane parameters such as solute permeability and reflection coefficient were determined to characterise the membrane. It was found that the flux for black liquor was comparatively lower than other solutes such as polyethylene glycol which could be attributed to the increased thickness of the polarised layer. Bhattacharjee and Bhattacharya ${ }^{17}$ studied the performance of ultrafiltration of black liquor by using a laboratory fabricated stirred and rotating disk batch ultrafiltration cell. The study was carried out as an attempt to minimise flux decline in order to obtain enhanced flux for the treatment of black liquor obtained from sulfite-pulping industries. The authors concluded that membrane rotating was more efficient in reducing concentration polarisation compared to stirring action. However, it is worth mentioning that the lignin dissolved from such alkaline sulfite pulping processes differs from kraft lignin.

The present work was undertaken to investigate the possibility of extracting lignin from black liquor generated from South African kraft mill black liquors. To our knowledge, a study of this nature has not been conducted in the South African context, so it is expedient to study the feasibility of ultrafiltration of lignin in black liquors from South African mills. In this study, the effects of operating pressure, membrane cut-off size, stirring rate and feed concentration on the extent of lignin retention and permeate flux were investigated. It has to be emphasised that only the effects of these parameters were investigated: the study did not include the optimisation of the parameters as the results from a stirred cell study cannot be applied on an industrial scale. The results only assist in the scale up of the process to a continuous pilot plant scale which is industrially relevant. The role of fouling is also monitored in the study and the results reported.

\section{Materials and methods}

\section{Materials}

Black liquor was procured from a South African eucalyptus kraft mill. The black liquor was diluted with deionised water to get the desired concentrations. Hydrophilic polyethersulfone membranes with molecular cut-off sizes of $5 \mathrm{kDa}, 10 \mathrm{kDa}$ and $20 \mathrm{kDa}$ were procured from Memcon (Pty) Ltd, South Africa. The membranes are usable in the $\mathrm{pH}$ range 0-14 and are resistant to temperatures up to $95^{\circ} \mathrm{C}$. The composition of the black liquor used is reported in Table 1.

Table 1: Concentrations of selected fractions in black liquor

\begin{tabular}{|c|c|}
\hline Analyte & $\%(\mathrm{~m} / \mathrm{m})$ \\
\hline Total solids content & 14.53 \\
\hline Lignin & 4.53 \\
\hline Ash content (dry basis) & 9.02 \\
\hline Water content & 84.97 \\
\hline \multicolumn{2}{|l|}{ Hemicelluloses (sugars) } \\
\hline Xylose & 0.03 \\
\hline Arabinose & 0.02 \\
\hline Galactose & 0.01 \\
\hline
\end{tabular}

\section{Apparatus}

A stirred dead-end filtration configuration as shown in Figure 1 was employed for the ultrafiltration experiments. The stirred cell (Amicon 8400, Merck, South Africa) had a volume of $400 \mathrm{~mL}$ and a diameter of $76 \mathrm{~mm}$. The cell was connected to a compressed air cylinder; the pressure in the cell was controlled by adjusting the pressure regulator on the outlet side of the cylinder and was monitored by a calibrated pressure gauge on the inlet of the cell. The effective filtration area of the cell was $41.8 \mathrm{~cm}^{2}$ and the clearance between the flat stirrer hanging from the top inside the cell and the membrane was $1.5 \mathrm{~mm}$. Stirring inside the cell was accomplished by using a magnetic stirrer with a digital display (MS-H280-Pro, Scilogex, USA). A constant temperature in the cell during operation was achieved by means of a heating copper coil inserted around the stirred cell body. Water from a heating bath was circulated in the heating coil using a peristaltic pump (323, Watson Marlow, South Africa).

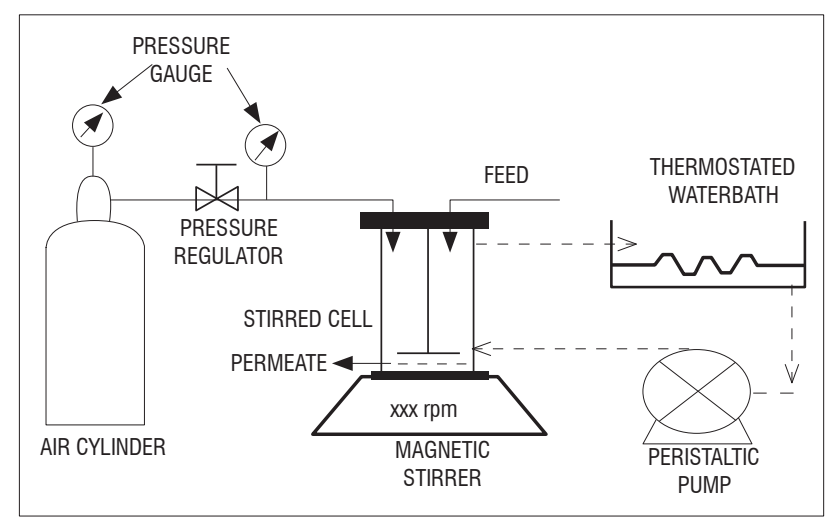

Figure 1: Schematic of the batch ultrafiltration set-up.

\section{Analysis}

The total dissolved solids concentration was determined gravimetrically by evaporating a known volume of black liquor sample at $105^{\circ} \mathrm{C}$ for $24 \mathrm{~h}$ and determining the weight of the residue. The ash content was measured by heating the residue from the total dissolved solids measurement to $950{ }^{\circ} \mathrm{C}$ and weighing the sample afterwards. The ash content is indicative of the concentration of inorganic matter in the sample. Lignin can be measured from the light absorption at a wavelength of $280 \mathrm{~nm}$ as it contains phenolic groups which absorb light. A UV-visible spectrophotometer (Varian CARY 50 CONC) was used to measure the UV light absorption of the black liquor samples. Where necessary, the samples were diluted with $0.1 \mathrm{M} \mathrm{NaOH}$ and an absorption constant of $24.6 \mathrm{~L} / \mathrm{g} . \mathrm{cm}$ was used. The hemicellulose (sugar) content of the black liquor was determined using high-performance liquid chromatography, comprising an autosampler (Perkin Elmer, Series 200), column oven (Perkin Elmer, Series 200), chromatography interface (Perkin Elmer, 600 Series), pulsed amperometric detector (Dionex) and analytical column (CarboPac PA-1, Dionex). The black liquor was first adjusted to a pH of 5 to 6 using $6 \mathrm{~mol} / \mathrm{L} \mathrm{HCl}$ and then the sugars were hydrolysed via heating with $4 \% \mathrm{H}_{2} \mathrm{SO}_{4}$ at $121{ }^{\circ} \mathrm{C}$ for $1 \mathrm{~h}$. The mass balance of selected analytes indicated that the error from analysis did not exceed 10\% (see Supplementary tables 1 and 2 of the supplementary material).

\section{Ultrafiltration procedure}

Ultrafiltration experiments were carried out to investigate the effect on lignin retention and transient flux decline of three variables: transmembrane pressure $(150,250$ and $350 \mathrm{kPa})$, stirring rate $(200$, 300 and $400 \mathrm{rpm}$ ) and feed concentration (3, 6 and $9 \mathrm{wt} \%$ ). One parameter was varied as the others were held constant to get an exact picture on dependence. All experiments were conducted at $60{ }^{\circ} \mathrm{C}$ by circulating a heating water stream at $95{ }^{\circ} \mathrm{C}$ and $15 \mathrm{rpm}$ in the coil around the stirred cell body. The disk membrane was placed on the porous support and the cell was assembled. Pure water flux at different transmembrane pressures was measured and plotted against the transmembrane pressure. The membrane resistance for each membrane was calculated from the slope of this plot. This calculation was followed by the actual experiment by charging the cell with $200 \mathrm{~mL}$ black liquor solution. The transmembrane pressure and stirrer speed were adjusted to desired levels using a pressure regulator and the speed controller on the magnetic stirrer, respectively. The duration of each experiment was $1 \mathrm{~h}$ and permeate at different time intervals was measured by collecting 
$10 \mathrm{~mL}$ of permeate in a measuring cylinder and recording the time of this collection. The retentate was collected by opening the stirred cell after each run. After each run, the cell was dismantled and the membrane thoroughly washed with deionised water to remove any deposition. The membrane was soaked in distilled water overnight and pure water flux was checked again to observe any variation in its hydraulic resistance before its reuse. This procedure was repeated after every experiment.

\section{Results and discussion}

\section{Membrane hydraulic resistance}

The hydraulic resistance of each membrane investigated was determined by recording the pure water flux as a function of pressure in the stirred cell and obtaining a linear relationship between the two parameters for each membrane. The membrane resistance $R_{\mathrm{M}}$ was calculated from Equation $1^{18}$ and the results are shown in Table 2.

$R_{M}=\frac{\Delta P}{\mu_{w} J_{w}}$

Equation 1

where $\Delta P$ is the transmembrane pressure, $J_{W}$ is the pure water flux and $\mu_{\mathrm{w}}$ is the viscosity of water with the effect of temperature taken into consideration.

Table 2: Membrane hydraulic resistances $\left(R_{M}\right)$ of all investigated membrane sizes

\begin{tabular}{c|c}
\hline \hline Membrane cut-off size (KDa) & \left.${\mathbf{( 1 0 ^ { 1 2 }}}^{-1}\right)$ \\
\hline 5 & 14.5 \\
\hline 10 & 5.08 \\
\hline 20 & 3.39 \\
\hline
\end{tabular}

From Table 2 it is observed that the membrane resistance increased with decreasing cut-off size of the membrane. This finding was expected, because for membranes with lower molecular weight cut-off, the pore sizes become constricted and a reduction in flux is expected.

\section{Stirred cell ultrafiltration of black liquor}

Stirred cell ultrafiltration tests were conducted to investigate the effects of operating pressure, stirring rate and feed concentration on the extent of retention and flux. Polyethersulfone membranes were used and the pressure, feed concentration and stirring rate were varied in the range $150-350 \mathrm{kPa}, 3-9 \%$ and $200-400 \mathrm{rpm}$, respectively. The lignin retention in the stirred cell was calculated as follows ${ }^{19}$.

$R=\frac{\ln \left(C_{R} / C_{F}\right)}{\ln (V C F)}=\frac{\ln \left[V C F-\left(C_{p} / C_{F}\right)(V C F-1)\right]}{\ln (V C F)}$

Equation 2

where $C_{F}, C_{P}$ and $C_{B}$ are the feed, permeate and retentate concentrations $(\mathrm{g} / \mathrm{L})$, respectively, and VCF is the volume concentration factor (dimensionless). Lignin retention values calculated in this manner consider either the retentate or the permeate concentrations, and the corresponding VCF ratio, allowing comparison of retention values throughout the process. VCF is dimensionless and given as ${ }^{19}$ :

$\mathrm{VCF}=\frac{\mathrm{V}_{\mathrm{F}}}{\mathrm{V}_{\mathrm{R}}}$

Equation 3

where $V_{F}$ and $V_{R}$ are the feed and retentate volumes, respectively. The VCF can be useful in the calculation of observed retention values of a solute during batch processes. ${ }^{19}$

Typical lignin analysis results obtained from the study are tabulated in Table 3. These are for pressure variation experiments in which the stirring speed and feed concentration were fixed at $200 \mathrm{rpm}$ and $9 \%$, respectively. From Table 3, it can be seen that the lignin fraction was concentrated in the retentate stream (for example at an operating pressure of $350 \mathrm{kPa}$ ); the lignin concentration increased to $81.2 \mathrm{~g} / \mathrm{L}$ from $36.4 \mathrm{~g} / \mathrm{L}$ in the raw sample. As is also shown in Table 3, the error associated with the analysis was below $10 \%$. All results from other experiments showed a similar trend (data not shown).

\section{Membrane selection}

Ultrafiltration was carried out in a stirred cell with three membranes that had cut-off sizes of $5 \mathrm{kDa}, 10 \mathrm{kDa}$ and $20 \mathrm{kDa}$, because black liquor is a polydispersed solution containing solutes within a wide distribution of molecular weights (and sizes) ranging from 100 to 100000 . The selection of a membrane cut-off size is therefore important for the efficiency of the process. ${ }^{15}$ The variation of retention and flux with pressure are shown in Figures 2 and 3, respectively. For this study, the feed concentration and stirring rate were fixed at $9 \%$ and $250 \mathrm{rpm}$, respectively. In Figure 2, it is shown that retention increased when a membrane with a lower cut-off size was used. For instance, at a transmembrane pressure of $150 \mathrm{kPa}$, retention was $83.9 \%$ for the $5-\mathrm{kDa}$ membrane, whereas under the same experimental conditions, the retention of the $20-\mathrm{kDa}$ membrane was $56.1 \%$. The same trend was observed for the entire pressure range tested. The results show that membranes with higher cut-off sizes allow more solutes with sizes less than the pore size of that particular membrane to pass through.

The initial permeate flux, as shown in Figure 3, was found to be comparatively higher for membranes with higher cut-off sizes for an operating pressure of $150 \mathrm{kPa}$. The initial permeate flux for the $5-\mathrm{kDa}$ membrane was comparatively lower at $15.1 \mathrm{~L} / \mathrm{m}^{2} \mathrm{~h}$ and it remained fairly constant throughout the course of the run.

For the $10-\mathrm{kDa}$ membrane it was $33.1 \mathrm{~L} / \mathrm{m}^{2} \mathrm{~h}$, which was a twofold increase in flux compared to that of the $5-\mathrm{kDa}$ membrane. This flux was maintained at $33.1 \mathrm{~L} / \mathrm{m}^{2} \mathrm{~h}$ for $30 \mathrm{~min}$ and started to decrease gradually thereafter. For the 20-kDa membrane, the flux was $47.9 \mathrm{~L} / \mathrm{m}^{2} \mathrm{~h}$ (an almost $45 \%$ increase compared to that of the $10-\mathrm{kDa}$ membrane) and it could only be maintained for 20 min, after which it started to decrease rapidly during the course of the run. The decline in permeate flux for the $10-\mathrm{kDa}$ and $20-\mathrm{kDa}$ membranes can be attributed to the deposition of the solute particles in the membrane pores as well as build-up of the deposited layer on the membrane surface. The combined effect of these resulted in a reduction in permeate flux during the course of operation. ${ }^{15}$

Table 3: $\quad$ Lignin mass balance (at a stirring rate of $200 \mathrm{rpm}$ and feed concentration of $9 \%$ )

\begin{tabular}{|c|c|c|c|c|c|c|c|c|c|}
\hline \multirow[t]{2}{*}{$\begin{array}{l}\text { Experimental } \\
\text { conditions }\end{array}$} & \multicolumn{2}{|c|}{ Lignin concentration $(\mathrm{g} / \mathrm{L})$} & \multicolumn{2}{|c|}{$\begin{array}{l}\text { Sample volume after run } \\
\qquad(\mathrm{mL})\end{array}$} & \multicolumn{2}{|c|}{$\begin{array}{l}\text { Calculated mass of lignin } \\
\text { in sample ( } \mathrm{g})\end{array}$} & \multicolumn{2}{|c|}{ Lignin (\% in feed) } & \multirow[t]{2}{*}{ Analysis error (\%) } \\
\hline & Permeate & Retentate & Permeate & Retentate & Permeate & Retentate & Permeate & Retentate & \\
\hline $150 \mathrm{kPa}$ & 15.87 & 61.6 & 106 & 94 & 1.71 & 5.67 & 23.54 & 77.86 & -1.41 \\
\hline $250 \mathrm{kPa}$ & 13.19 & 62.5 & 108 & 92 & 1.39 & 5.87 & 19.20 & 80.73 & 0.07 \\
\hline $350 \mathrm{kPa}$ & 13.54 & 81.17 & 131 & 69 & 1.77 & 5.60 & 24.36 & 76.95 & -1.31 \\
\hline Raw sample & \multicolumn{2}{|c|}{36.39} & \multicolumn{2}{|c|}{200} & \multicolumn{2}{|c|}{7.28} & & & \\
\hline
\end{tabular}




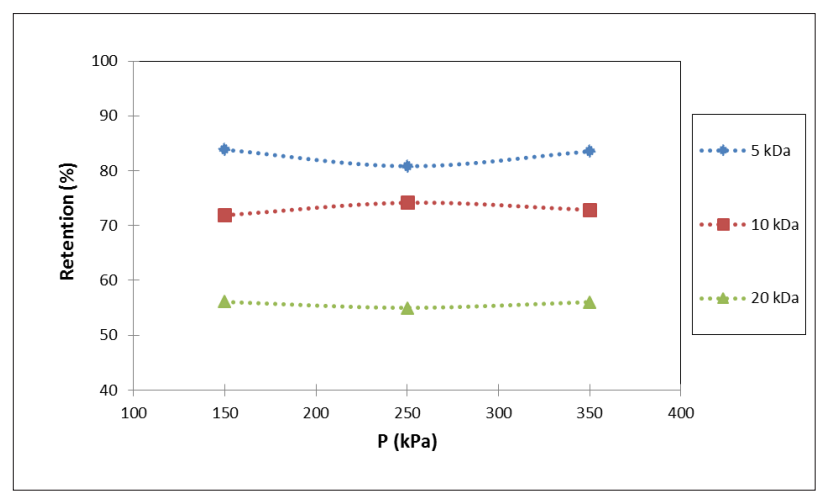

Figure 2: Variation in lignin retention with pressure for different membranes in a stirred cell (at a stirring speed of $250 \mathrm{rpm}$ and a feed concentration of $9 \%$ ).

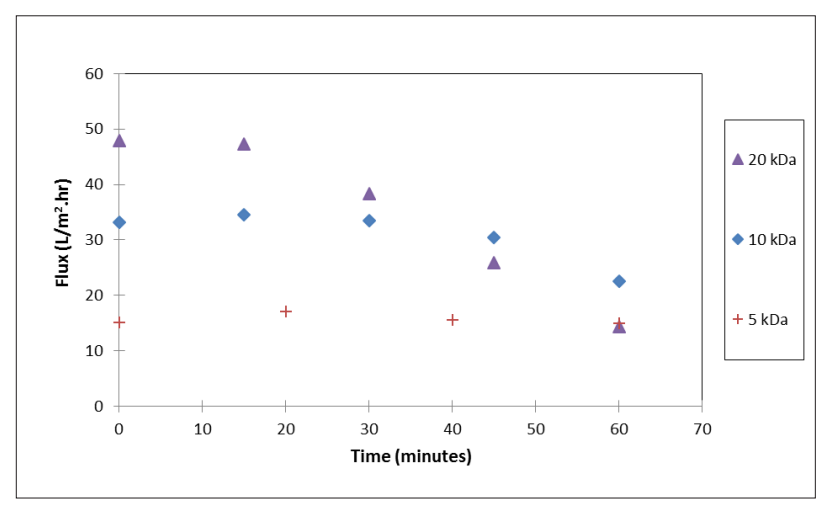

Figure 3: Variation in permeate flux as a function of time for different membranes in a stirred cell (at a stirring speed of $300 \mathrm{rpm}$, feed concentration of $9 \%$ and pressure of $150 \mathrm{kPa}$ ).

\section{Effect of pressure on lignin retention and permeate flux}

Figures 4 and 5 represent the effect of pressure on retention and permeate flux, respectively. For this study, a 10-kDa membrane was used and Figure 4 is plotted for feed concentrations 3\%, 6\% and $9 \%$. An increase in pressure from $150 \mathrm{kPa}$ to $250 \mathrm{kPa}$, as shown in Figure 4, resulted in only a marginal increase in the retention of lignin of less than $2 \%$ for each concentration tested. However, for the $6 \%$ and $9 \%$ solutions, as the pressure was increased further from $250 \mathrm{kPa}$ to $350 \mathrm{kPa}$, the retention increased from $60.7 \%$ to $67.3 \%$ and from $73.8 \%$ to $79.5 \%$, respectively. This increase was attributed to the fact that, as the pressure is increased, the convective diffusion of solutes to the membrane surface is increased, which in turn results in severe concentration polarisation. This polarisation leads to an increase in viscosity of the solution near the membrane surface as the higher molecular weight organics are retained by the membrane and this viscous layer is responsible for pre-sieving of the organic solutes. ${ }^{12}$

The high initial permeate flux values at higher pressures are as a result of an increase in driving force of the solvent through the membrane, as shown in Figure 5. However, the decrease in permeate flux during the course of operation is rapid for higher pressures. For ultrafiltration at $350 \mathrm{kPa}$, after $20 \mathrm{~min}$, the flux declined by $45 \%$ from $50.66 \mathrm{~L} / \mathrm{m}^{2} \mathrm{~h}$ to $27.7 \mathrm{~L} / \mathrm{m}^{2} \mathrm{~h}$ whereas that for ultrafiltration at $250 \mathrm{kPa}$ declined by $28 \%$ from $41.0 \mathrm{~L} / \mathrm{m}^{2} \mathrm{~h}$ to $29.7 \mathrm{~L} / \mathrm{m}^{2} \mathrm{~h}$ in the same time interval. For ultrafiltration at $150 \mathrm{kPa}$, after $20 \mathrm{~min}$, only a 15\% decline in permeate flux (from 28.1 to $23.9 \mathrm{~L} / \mathrm{m}^{2} \mathrm{~h}$ ) was observed. This difference is because the rate of deposition of solutes on the membrane surface occurs at a faster rate as the pressure is increased, which reduces the net driving force of the solvent transport through the membrane as a result of the increase in osmotic pressure of the solution at the surface. Furthermore, the deposited layer becomes compact at higher pressures, which increases the resistance against the solvent. ${ }^{12,15,20}$

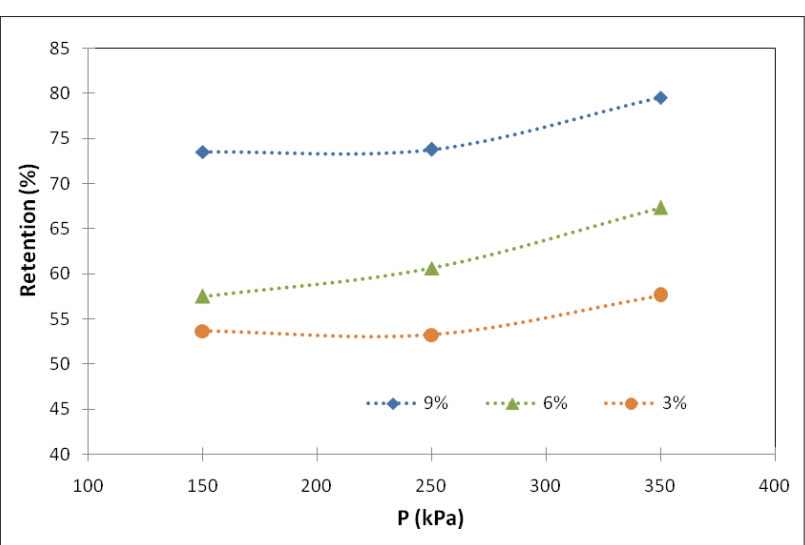

Figure 4: Variation in lignin retention with pressure at different feed concentrations in a stirred cell (with a membrane size of $10 \mathrm{kDa}$ and a stirring speed of $300 \mathrm{rpm}$ ).

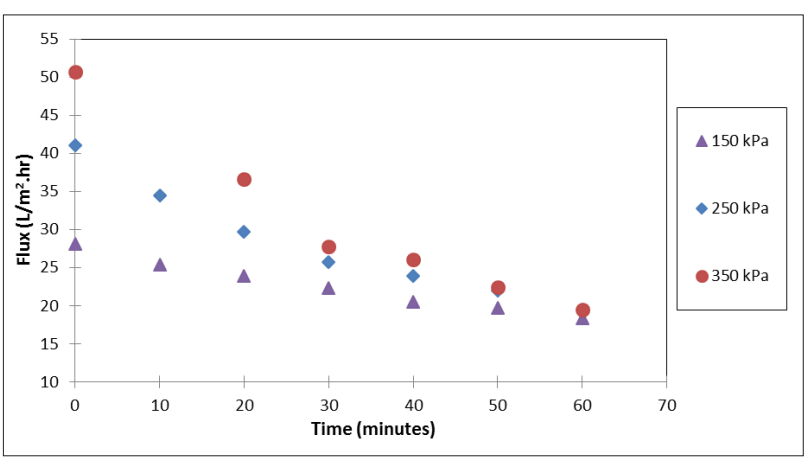

Figure 5: Variation in permeate flux as a function of time at different pressures in a stirred cell (at a feed concentration of $6 \%$ and stirring speed of $200 \mathrm{rpm}$ with a membrane size of $10 \mathrm{kDa}$ ).

\section{Effect of feed concentration on lignin retention and permeate flux}

The effect of black liquor feed concentration on the extent of retention and flux are described in Figures 6 and 7. For this study, a 10-kDa membrane was used and the stirring rate was fixed at $300 \mathrm{rpm}$ for all experiments. The retention of lignin in the stirred cell increased with an increase in feed concentration in the entire range tested, as shown in Figure 6 . For instance, at an operating pressure of $350 \mathrm{kPa}$, an increase in feed concentration from $3 \%$ to $9 \%$ resulted in an increase in retention from $54.8 \%$ to $72.3 \%$. For an operating pressure of $250 \mathrm{kPa}$, the extent of retention increased from $30.1 \%$ to $66.9 \%$ as the feed concentration was increased in the same range. This difference can be explained by the fact that as the ultrafiltration process proceeds, the viscosity of the solution near the membrane surface increases as a result of organic solutes that are rejected by the membrane. ${ }^{12}$ This layer serves to sieve organic solutes. Because the viscosity of black liquor is dependent on its concentration, increasing the feed concentration of the solution results in an increase in the rate of formation of the viscous layer near the membrane surface as well as its viscosity. Black liquor components have a molecular weight (and size) distribution ranging from $100 \mathrm{Da}$ to $100000 \mathrm{Da}$; therefore, when a viscous layer is formed near the membrane surface, the retention of low molecular weight lignin fractions that would, under normal circumstances, permeate through the membrane are retained, thus increasing the retention. ${ }^{15}$ The same trend was observed for other operating pressures tested but it has to be highlighted that, at a constant feed concentration, higher operating pressures resulted in higher retention values. For example, at a fixed feed concentration of $6 \%$, increasing the pressure from $250 \mathrm{kPa}$ to $350 \mathrm{kPa}$ resulted in an increase in retention from $41.9 \%$ to $57.9 \%$. This increase is because at a higher pressure the viscous layer formed at the membrane surface becomes more compact, which enhances its ability to sieve low molecular weight lignin fractions. ${ }^{12,15}$ 


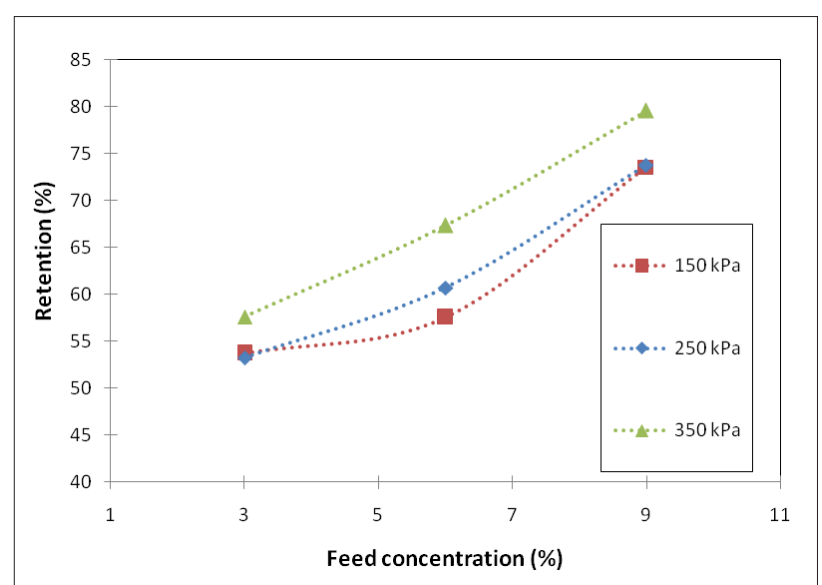

Figure 6: Variation in lignin retention with feed concentration at different pressures in a stirred cell (at a stirring speed of $200 \mathrm{rpm}$ and a membrane size of $10 \mathrm{kDa}$ ).

The variation of permeate flux as a function of time for different feed concentrations is displayed in Figure 7 . It was observed that the initial permeate flux, as shown in Figure 7, was comparatively higher for less concentrated solutions. The initial flux readings were $95.7 \mathrm{~L} / \mathrm{m}^{2} \mathrm{~h}, 62.9 \mathrm{~L} / \mathrm{m}^{2} \mathrm{~h}$ and $44.2 \mathrm{~L} / \mathrm{m}^{2} \mathrm{~h}$ for the $3 \%, 6 \%$ and $9 \%$ solutions, respectively. The variation with initial flux as a function of feed concentration is as a result of osmotic pressure resistance which is established within seconds of operation and this resistance is strongly dependent on feed concentration. ${ }^{11}$ The reduction in flux with an increase in feed concentration is because the bulk concentration in the stirred cell increases as the solutes are rejected by the membrane, which in turn increases the extent of solute deposition near the membrane surface. The flux is reduced as the resistance to solvent transport through the membrane is increased in the polarised layer. ${ }^{21}$ It is worth noting from Figure 7 that, after a filtration duration of $20 \mathrm{~min}$, the permeate flux for the $6 \%$ and $9 \%$ solutions reached the same value and decreased at the same rate until the end of the filtration run. Also after $40 \mathrm{~min}$, the same flux reading was recorded for all solutions tested, which indicates the same magnitude of total resistance to flow. For the $3 \%$ solution, the rate of depletion of solvent in the stirred cell was comparatively higher, which resulted in the accelerated build-up of a deposited layer, and hence the flux reached the same value as that of the $6 \%$ and $9 \%$ solutions. For the $6 \%$ and $9 \%$ solutions, the osmotic pressure was comparatively higher because of an increased concentration which retards the rapid depletion of the solvent from the stirred cell, and hence the flux decreased gradually with time.

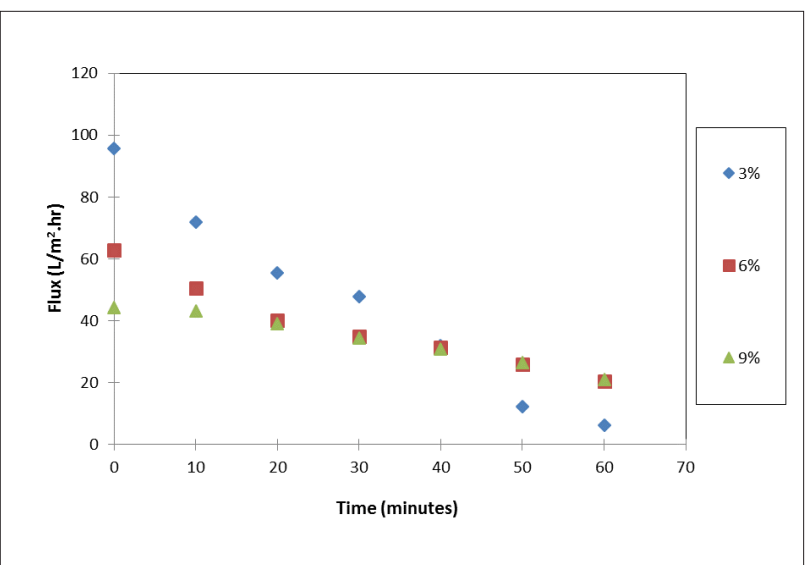

Figure 7: Variation in permeate flux as a function of time at different feed concentrations in a stirred cell (at a pressure of $250 \mathrm{kPa}$ and a stirring speed of $300 \mathrm{rpm}$, with a membrane size of $10 \mathrm{kDa}$ ).

\section{Effect of stirring rate on lignin retention and permeate flux}

Figures 8 and 9 show the variation of lignin retention and permeate flux, respectively, with stirring rate in the stirred cell. In Figure 8 it is shown that as the stirring rate is increased, there is a corresponding increase in lignin retention in the entire concentration range investigated. As the stirring rate was increased from $200 \mathrm{rpm}$ to $400 \mathrm{rpm}$, there was a corresponding increase in retention from $59.9 \%$ to $73.6 \%$ for the $3 \%$ solution. For the $6 \%$ and $9 \%$ solutions, the extent of retention increased from $61.5 \%$ to $79.1 \%$ and from $67.8 \%$ to $86.6 \%$, respectively. A possible explanation for this observation is that at a low stirring speed, the rate of diffusion of solutes from the membrane surface to the bulk solution is comparatively lower as a result of the significant reduction in the influence of external forced convection that is induced by stirring. Because black liquor is a polydispersed solution, there is a possibility that lignin fractions with molecular weight sizes that are less than the cut-off size of the membrane permeate through the membrane, thus reducing the extent of retention. The backward diffusion of solute from the membrane surface to the bulk is enhanced as the stirring rate in the stirred cell is increased, and forced convection of solutes prevents them from being deposited on the membrane surface. This prevention in turn minimises the possibility of the low molecular weight lignin fractions from permeating through, thus increasing the extent of retention.

The variation of flux as a function of time at different stirring rates is represented by Figure 9 . This study was conducted with a solution of $3 \%$ and operating pressure of $150 \mathrm{kPa}$. As the stirring rate increased from $200 \mathrm{rpm}$ to $300 \mathrm{rpm}$, as shown in Figure 9, the initial permeate flux increased from $55.2 \mathrm{~L} / \mathrm{m}^{2} \mathrm{~h}$ to $81.3 \mathrm{~L} / \mathrm{m}^{2} \mathrm{~h}$. This increase results because as the rate of backward diffusion of solutes from the membrane surface to the bulk is enhanced by an increase in stirring rate, there is less buildup of osmotic pressure and the greater effective pressure difference results in an increase in flux. ${ }^{15} \mathrm{It}$ is worth noting that in the $20-40$ min time interval, the fluxes for $300 \mathrm{rpm}$ and $400 \mathrm{rpm}$ were approximately equal to each other, indicating that the extent of minimisation of osmotic pressure at the membrane surface was approximately the same as the stirring rate was increased above $300 \mathrm{rpm}$. This means the resistance to permeation of the solvent was approximately the same in that specific time interval. The rapid decline in permeate flux for stirring rates of $300 \mathrm{rpm}$ and $400 \mathrm{rpm}$ was as a result of an increase in the bulk solution viscosity which increased the osmotic pressure (the extent of the increase is minimised by stirring) as the solvent permeated through the membrane at a faster rate than at $200 \mathrm{rpm}$. This supposition is substantiated by the significant deviation in flux values for $300 \mathrm{rpm}$ and $400 \mathrm{rpm}$ in the 50-60 min time interval. This deviation indicates that the resistance to solvent flow at a stirring rate of $300 \mathrm{rpm}$ increases as a result of the slower back diffusion of solute from the membrane surface as the viscosity and concentration of the solution increases. At $400 \mathrm{rpm}$, this effect is offset by the faster rate of back diffusion of solute from the surface, which minimises the increase in osmotic pressure/resistance.

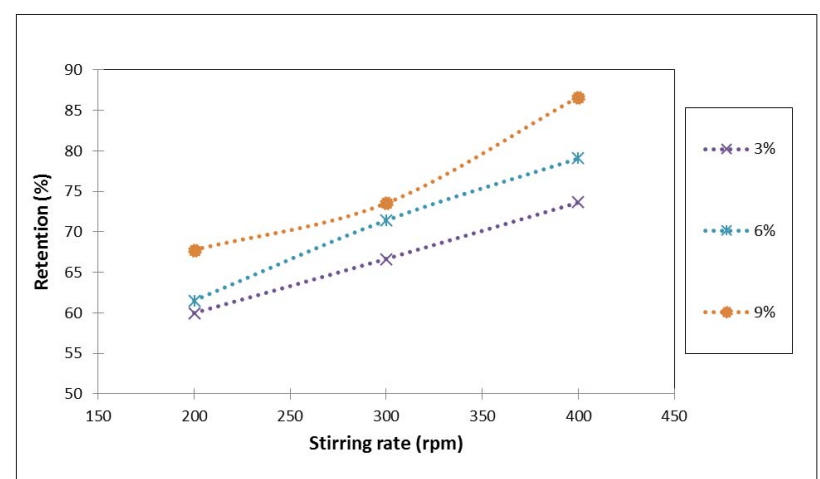

Figure 8: Variation of lignin retention with stirring rate at different feed concentrations in a stirred cell (at a pressure of $150 \mathrm{kPa}$ with a membrane size of $10 \mathrm{kDa}$ ) 


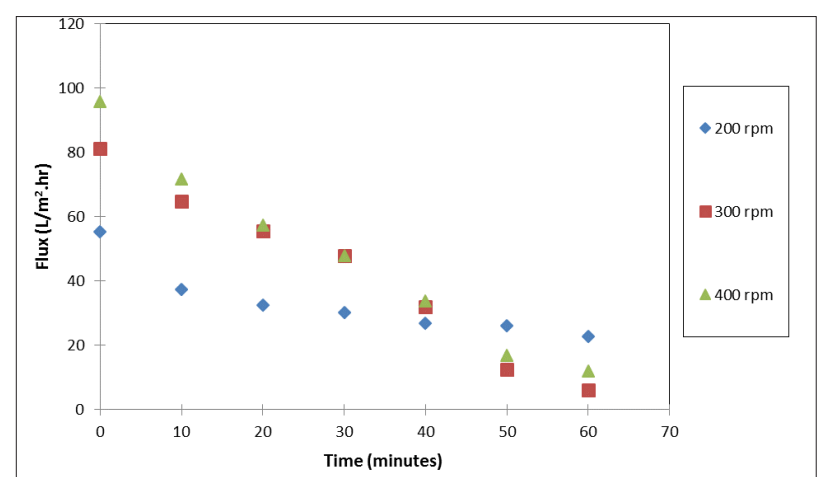

Figure 9: Variation of permeate flux as a function of time at different stirring rates in a stirred cell (at a pressure of $150 \mathrm{kPa}$ and a feed concentration of $3 \%$ with a membrane size of $10 \mathrm{kDa}$ ).

\section{Solids content analysis}

Table 4 represents the ash content analysis results of the fractions collected at the end of the ultrafiltration runs. An optimum membrane cut-off size should result in minimal retention of cooking chemicals (i.e. sodium and sulfur). In addition to the fact that these chemicals have to be reused in the cooking process, it is necessary to avoid forming ash and sulfur dioxide when these inorganic elements are combusted in a normal furnace. ${ }^{22}$ The increase in ash content in the retentate fractions is as a result of the retention of multivalent ions that are associated with the retained organic matter. For example, for the 5-kDa membrane and an operating transmembrane pressure of $150 \mathrm{kPa}$, as observed in Table 4, the ash content increased from $5.8 \%$ (raw) to $7.1 \%$ (retentate stream). The same trend was observed for all different combinations of membrane cut-off size and process conditions (data not shown). This result was also observed by Wallberg et al. ${ }^{22}$ when they used polymeric and ceramic membranes to fractionate and concentrate black liquor. The ash that is observed in the permeate streams is attributed to monovalent ions as their retention is insignificant.22

Table 5 shows the solids content analysis results of the fractions collected at the end of the ultrafiltration runs. The increase in solids content in the retentate streams as the pressure is increased, with the other variables (membrane cut-off size, stirring speed, feed concentration) maintained at constant values, is attributed to the increase in driving force which accelerated the rate of solvent permeation out of the stirred cell, resulting in the increased concentration of the retentate stream. ${ }^{15}$ For example, for the 10-kDa membrane, as recorded in Table 5, the solids content in the retentate stream increased from $11.2 \%$ to $15.4 \%$ as the pressure was increased from $150 \mathrm{kPa}$ to $350 \mathrm{kPa}$. The same trend (i.e. the concentration of solids in the retentate stream) was observed for all different combinations of membrane cut-off size and process conditions (data not shown).

\section{Conclusions}

A bench-scale study was conducted to investigate the feasibility of extracting lignin, by means of ultrafiltration, from black liquor generated using hardwoods sourced from the southern African region. It was found that amongst the membranes investigated, the highest retention of lignin was achieved using the 5-kDa membrane. Although the 5-kDa size membrane had the highest retention, its flux was too low for a comparative study. Therefore, to investigate the effect of operating parameters on both the flux and retention, a 10-kDa size membrane was used. The parameters investigated (operating pressure, feed concentration and stirring rate) had significant effects on the retention of lignin and flux and it would be worthwhile to investigate them further on a pilot plant scale. Membrane fouling was observed to have a profound negative effect on flux values in the study and the mechanisms that contributed to this were combinations of osmotic pressure build up and the development of a viscous gel layer on the membrane during operation. This study should be augmented by studying the ultrafiltration of lignin in a pilot plant in a continuous mode to (1) overcome the effect of fouling associated with batch filtration and (2) to generate a set of data that can be applicable to ultrafiltration of black liquor on an industrial scale.

\section{Acknowledgements}

We thank the University of KwaZulu-Natal and the Council for Scientific and Industrial Research for providing office and laboratory facilities as well as financial assistance for project costs and a postgraduate scholarship.

\section{Authors' contributions}

This work forms part of P.K.'s MSc dissertation, thus he was responsible for performing the experiments, for laboratory analysis and for writing the manuscript. B.S. is the corresponding author and project leader; he supervised and reviewed the work and gave comments on the manuscript. D.R. acted as co-supervisor during the MSc study, assisted with the experimental design and analysis of results and provided comments on the manuscript.

Table 4: $\quad$ Ash content analysis (\%) of ultrafiltration fractions from the membrane selection study

\begin{tabular}{c|c|c|c|c|c|c}
\hline \hline \multirow{2}{*}{ Pressure (kPa) } & \multicolumn{7}{|c}{ Membrane cut-off size (kDa) } \\
\cline { 2 - 8 } & \multicolumn{2}{|c|}{$\mathbf{5}$} & \multicolumn{2}{c}{$\mathbf{1 0}$} & \multicolumn{2}{c}{$\mathbf{2 0}$} \\
\cline { 2 - 8 } & Permeate & Retentate & Permeate & Retentate & Permeate & Retentate \\
\hline 150 & 4.14 & 7.09 & 4.61 & 8.85 & 5.5 & 9.49 \\
\hline 250 & 4.27 & 8.83 & 4.7 & 8.7 & 4.52 & 11.22 \\
\hline 350 & 3.9 & 8.75 & 4.61 & 10.46 & 4.82 & 12.07 \\
\hline
\end{tabular}

Table 5: $\quad$ Solids content analysis (\%) of ultrafiltration fractions from the membrane selection study

\begin{tabular}{|c|c|c|c|c|c|c|}
\hline \multirow{3}{*}{ Pressure (kPa) } & \multicolumn{6}{|c|}{ Membrane cut-off size (kDa) } \\
\hline & \multicolumn{2}{|c|}{5} & \multicolumn{2}{|c|}{10} & \multicolumn{2}{|c|}{20} \\
\hline & Permeate & Retentate & Permeate & Retentate & Permeate & Retentate \\
\hline 150 & 5.55 & 9.54 & 5.37 & 11.18 & 6.55 & 13.78 \\
\hline 250 & 4.73 & 12.72 & 5.45 & 12.91 & 6.17 & 16.12 \\
\hline 350 & 4.94 & 14.54 & 5.6 & 15.38 & 6.21 & 17.72 \\
\hline
\end{tabular}




\section{References}

1. Wallberg 0 , Linde $M$, Jönsson $A$. Extraction of lignin and hemicelluloses from kraft black liquor. Desalination. 2006;199:413-414. http://dx.doi. org/10.1016/j.desal.2006.03.094

2. Dafinov A, Font J, Garcia-Valls R. Processing of black liquors by UF/NF ceramic membranes. Desalination. 2005;173(1):83-90. http://dx.doi. org/10.1016/j.desal.2004.07.044

3. Moshkelani M, Marinova M, Perrier M, Paris J. The forest biorefinery and its implementation in the pulp and paper industry: Energy overview. Appl Therm Eng. 2013;50(2):1427-1436. http://dx.doi.org/10.1016/j. applthermaleng.2011.12.038

4. Toledano A, García A, Mondragon I, Labidi J. Lignin separation and fractionation by ultrafiltration. Sep Purif Technol. 2010;71(1):38-43. http:// dx.doi.org/10.1016/j.seppur.2009.10.024

5. Chatel G, Rogers RD. Review: Oxidation of lignin using ionic liquids - An innovative strategy to produce renewable chemicals. ACS Sustainable Chem Eng. 2014;2(3):322-339. http://dx.doi.org/10.1021/sc4004086

6. Jönsson $A$, Wallberg 0 . Cost estimates of kraft lignin recovery by ultrafiltration. Desalination. 2009;237(1-3):254-267. http://dx.doi.org/10.1016/j. desal.2007.11.061

7. Banerjee S, De S. An analytical solution of Sherwood number in a stirred continuous cell during steady state ultrafiltration. J Membr Sci. 2012;389:188196. http://dx.doi.org/10.1016/j.memsci.2011.10.029

8. Alekhina M, Ershova O, Ebert A, Heikkinen S, Sixta H. Softwood kraft lignin for value-added applications: Fractionation and structural characterization. Ind Crop Prod. 2015;66:220-228. http://dx.doi.org/10.1016/j. indcrop.2014.12.021

9. Jin W, Tolba R, Wen J, Li K, Chen A. Efficient extraction of lignin from black liquor via a novel membrane-assisted electrochemical approach. Electrochim Acta. 2013;107:611-618. http://dx.doi.org/10.1016/j.electacta.2013.06.031

10. Velez J, Thies MC. Solvated liquid-lignin fractions from a kraft black liquor. Bioresour Technol. 2013;148:586-590. http://dx.doi.org/10.1016/j. biortech.2013.08.097

11. Doherty WOS, Mousavioun P, Fellows CM. Value-adding to cellulosic ethanol: Lignin polymers. Ind Crop Prod. 2011;33(2):259-276. http://dx.doi. org/10.1016/j.indcrop.2010.10.022
12. De S, Bhattacharya PK. Flux prediction of black liquor in cross flow ultrafiltration using low and high rejecting membranes. J Membr Sci. 1996;109(1):109-123. http://dx.doi.org/10.1016/0376-7388(95)00188-3

13. Bhattacharjee C, Sarkar P, Datta S, Gupta BB, Bhattacharya PK. Parameter estimation and performance study during ultrafiltration of kraft black liquor. Sep Purif Technol. 2006;51(3):247-257. http://dx.doi.org/10.1016/j. seppur.2006.02.005

14. Jönsson A, Nordin A, Wallberg 0 . Concentration and purification of lignin in hardwood kraft pulping liquor by ultrafiltration and nanofiltration. Chem Eng Res Des. 2008;86(11):1271-1280. http://dx.doi.org/10.1016/j. cherd.2008.06.003

15. Satyanarayana SV, Bhattacharya PK, De S. Flux decline during ultrafiltration of kraft black liquor using different flow modules: A comparative study. Sep Purif Technol. 2000;20(2-3):155-167. http://dx.doi.org/10.1016/S13835866(00)00086-1

16. Bhattacharjee $\mathrm{C}$, Bhattacharya $\mathrm{PK}$. Flux decline analysis in ultrafiltration of kraft black liquor. J Membr Sci. 1993;82:1-14. http://dx.doi.org/10.1016/03767388(93)85088-E

17. Bhattacharjee $\mathrm{C}$, Bhattacharya PK. Ultrafiltration of black liquor using rotating disk membrane module. Sep Purif Technol. 2006;49(3):281-290. http:// dx.doi.org/10.1016/j.seppur.2005.10.011

18. Schwarze M, Le DK, Wille S, Drews A, Arlt W, Schomäcker R. Stirred cell ultrafiltration of aqueous micellar TX-100 solutions. Sep Purif Technol. 2010;74(1):21-27. http://dx.doi.org/10.1016/j.seppur.2010.05.003

19. Britz TJ, Robinson RK, editors. Advanced dairy science and technology. Oxford: Blackwell; 2008. http://dx.doi.org/10.1002/9780470697634

20. Noordman TR, Ketelaar TH, Donkers F, Wesselingh JA. Concentration and desalination of protein solutions by ultrafiltration. Chem Eng Sci. 2008;57(4):693-703. http://dx.doi.org/10.1016/S0009-2509(01)00403-1

21. Bhattacharjee $C$, Datta $S$. A mass transfer model for the prediction of rejection and flux during ultrafiltration of PEG-6000. J Membr Sci. 1997;125(2):303310. http://dx.doi.org/10.1016/S0376-7388(96)00247-5

22. Wallberg 0 , Jönsson $A$, Wimmerstedt R. Fractionation and concentration of kraft black liquor lignin with ultrafiltration. Desalination. 2003;154:187-199. http://dx.doi.org/10.1016/S0011-9164(03)80019-X 